\title{
Epiphytic Pseudomonas syringae on Dry Beans Treated with Copper-Based Bactericides
}

\author{
K. A. Garrett and H. F. Schwartz, Department of Agricultural Biosciences and Pest Management, Colorado State \\ University, Fort Collins, 80523-1177
}

\begin{abstract}
Garrett, K. A., and Schwartz, H. F. 1998. Epiphytic Pseudomonas syringae on dry beans treated with copper-based bactericides. Plant Dis. 82:30-35.

The response of epiphytic populations of Pseudomonas syringae and other bacteria on dry bean plants to four copper-based bactericides was evaluated. The bactericides showed little difference in efficacy, but epiphytic populations on pinto bean leaflets, flowers, and pods were occasionally reduced when compared to populations on non-treated control plants, especially after repeated bactericide applications. Although there was a trend toward a relationship between epiphytic leaflet and flower populations, there were cases where $P$. syringae was undetected on one organ but abundant in samples from the other organ. $P$. syringae pv. syringae strains recovered from epiphytic populations demonstrated much greater copper resistance than did strains of $P$. syringae pv. phaseolicola, as measured by growth on media amended with cupric hydroxide. This difference between the pathovars may have implications for integrated pest management strategies.
\end{abstract}

Bacterial brown spot (caused by Pseudomonas syringae pv. syringae van Hall) and halo blight (caused by $P$. syringae pv. phaseolicola (Burk.) Young, Dye, and Wilkie) are two important diseases of dry beans (Phaseolus vulgaris L.) in Colorado and other parts of the world (14). These bacterial pathogens are of particular interest for the following reasons. Though there is potential for using epiphytic population size to predict risk of disease $(12,19,20)$, little is actually known about how $P$. syringae spreads as an epiphyte or the relationship between natural leaflet populations and populations on flowers, pods, and seeds. There is concern that $P$. syringae populations may develop increased resistance to copper-based pesticides. A range of tolerance levels has been found in $P$. syringae pv. syringae from cherry orchards (29) and nurseries in the Pacific Northwest (26), for example, and plasmid-encoded copper resistance is being found more widely in several genera of phytopathogenic bacteria (5). Laboratory experiments indicate that plasmids conferring copper resistance can be transferred between

Current address of first author: Department of Botany and Plant Pathology, 2082 Cordley Hall, Oregon State University, Corvallis 97331-2902; E-mail: garrettk@bcc.orst.edu

This research was supported in part by the Colorado State University Agricultural Experiment Station and the Colorado Dry Bean Administrative Committee.

Accepted for publication 15 September 1997.

Publication no. D-1997-1107-02R

(C) 1998 The American Phytopathological Society pathovars of $P$. syringae $(1,2)$. Since both $P$. syringae pv. syringae and $P$. syringae $\mathrm{pv}$. phaseolicola overwinter in seed and plant debris and infect volunteer beans the following year, resistant populations could survive from season to season and jeopardize future management efforts with bactericides and other integrated pest management approaches such as planting certified seed, varietal selection, and crop rotation, among others (18).

The objectives of this research were to (i) estimate the effectiveness of different formulations of copper-based bactericides for reducing populations of epiphytic bacteria, (ii) examine the relationship between epiphytic populations on leaves and flowers, and (iii) determine levels of copper resistance present in $P$. syringae populations during exposure to copper-based bactericide regimes.

\section{MATERIALS AND METHODS}

Plot design and sampling procedure. A sprinkler-irrigated bean field at the Colorado State University Bay Farm research facility in Fort Collins was studied for 2 years. Plant debris contaminated with $P$. syringae pv. phaseolicola had been plowed under (1- to 30-cm depth) in the past, and the field had previously produced bean plants infected with halo blight. A nontreated control was compared with four formulations of copper-based bactericides: cupric hydroxide (Kocide 606, Griffin Corp., and Champion, Agtrol Chemical Products, 24\% metallic copper each) at 4.7 liters/ha; copper ammonium carbonate (Copper Count N, Mineral Research \& Development, 8\% metallic copper) at 7 liters/ha; and elemental copper from cop- per salts (Tenn-Cop, Boliden Intertrade, $5 \%$ metallic copper) at 3.5 liters/ha applied with a $\mathrm{CO}_{2}$ backpack sprayer with a 8003 type flat-fan nozzle over the top of each row. Plots were $6 \mathrm{~m}$ long with 4 rows spaced $0.56 \mathrm{~m}$ apart, a $1-\mathrm{m}$ alley, and a $4-$ row non-treated buffer between plots. Four replications of each treatment were arranged in randomized complete blocks. Samples for epiphytic population enumeration were collected at the times indicated in Table 1. In 1987, the susceptible pinto cultivar Olathe was planted. In 1986, the bean plants at this site were destroyed by a severe hail storm after the second sampling period; thus, no data are presented.

Studies of epiphytic bacteria on dry beans in eastern Colorado were conducted at four sites in 1986 and three sites in 1987; data are presented for only two fields each year ( 1 and 2 in 1986, 3 and 4 in 1987) where at least 2 epiphytic samples could be collected during the vegetative and/or flowering periods of plant development. The commercial bean fields were in the Holyoke area, Phillips County, planted with the pinto cultivar Olathe following a 1- to 2-year rotation with field corn. Each site received two treatments: a non-sprayed control and a weekly spray of cupric hydroxide (Kocide 606) at 4.7 liters/ha (2.5 $\mathrm{kg} \mathrm{Cu} / \mathrm{ha}$ ) in 477 liters water/ha. Plots were $12.2 \mathrm{~m}$ long with 4 rows spaced $0.76 \mathrm{~m}$ apart, a $1.5-\mathrm{m}$ alley, and a 4-row nontreated buffer between plots. Four replications of each treatment were arranged in a completely randomized design. Plant samples were collected the day following spray application. In 1986, field 2 was sprinklerirrigated; all other fields were furrow-irrigated. In 1987, all fields were furrow-irrigated.

Bulked samples of 40 symptomless leaflets, flowers, or pods were randomly selected from each plot at each sampling date. Three-quarter to fully expanded leaflets were collected from the upper onethird of the canopy. Flowers were collected when open but prior to yellowing after fertilization. Green pods sampled were 5 to $10 \mathrm{~cm}$ long. Samples were collected in the morning and stored in sealable plastic bags on ice for processing that afternoon. In the lab, samples were placed in $200 \mathrm{ml}$ of sterile phosphate buffer formulated to limit the action of copper in vitro (24), and shaken on a horizontal shaker for $1 \mathrm{~h}$. The resulting suspension was plated on King's 
medium B $(\mathrm{KB} ; 15)$ using a 10-fold dilution series. After 3 days' incubation at $22^{\circ} \mathrm{C}$, a most probable number method (9) was used to estimate the total number of bacteria and Pseudomonas syringae-type bacteria recovered. CFU/40 leaflets, flowers, or pods were used for analyses.

Population data taken from dilutions do not exhibit the complete range of values, because smaller counts cannot be detected. The detection limit for transformed data was $3.6 \log _{10}$ CFU/40 leaflets, flowers, or pods. One approach to dealing with this which might be viewed as "liberal" is to treat populations below the detection level as nonexistent. A "conservative" approach, in which undetectable populations were treated as present at the highest undetectable level of $3.6 \log _{10}$ CFU/40 organs, was used here. Hirano et al. (10) discuss some statistical issues involved in choosing a method for dealing with data censoring.

Because availability of symptomless leaflets, flowers, and pods varied greatly among fields and years, field-year combinations were evaluated as separate case studies. $P$ values were calculated for an analysis of variance at each sampling time for each plant organ. This resulted in a great number of separate tests, so the Bonferroni-corrected (23) cut-off for 0.05 probability of case-wise Type I error was calculated for each case study. The Bonferroni correction to the cut-off, simply $0.05 /$ no. tests per case, was based on the number of tests made after bactericides had been applied. For comparisons where responses from one treatment were all below the detection limit, the standard error from the other treatment was used for the test rather than a pooled estimate. For the Fort Collins site, blocks were included in the analysis of variance and a two-tailed Dunnett's test (6) was used to compare each treatment to the control at each date.

Analysis of strains. Pseudomonas syringae-type bacteria were identified for counting purposes by colony morphology and typical blue fluorescence on KB (15).
This identification was verified by additional tests on representative cultures purified and streaked onto Nutrient Glucose Agar (NGA; 25). These bacteria were then tested for oxidase production and identified as $P$. syringae pv. syringae or $P$. syringae pv. phaseolicola based upon carbon source utilization. Growth after 5 days at $22^{\circ} \mathrm{C}$ on Ayers et al. mineral salts medium (25) amended with the following carbon sources was used to determine utilization. Strains able to utilize quinic acid, myoinositol, D-mannitol, and betaine, but not Ltartaric acid or homoserine, were identified as $P$. syringae pv. syringae. Strains able to utilize quinic acid, but not L-tartaric acid, myo-inositol, D-mannitol, or homoserine were identified as $P$. syringae pv. phaseolicola. Strains collected in 1987 were also tested for acid production with sucrose as a sole carbon source by using Ayers et al. medium as above with an indicator to detect $\mathrm{pH}$ changes.

Randomly selected representative strains were also tested for ice nucleation activity. Cultures were incubated for two days to prepare suspensions of $10^{8} \mathrm{CFU}$ per $\mathrm{ml}$. Two test tubes, each containing $50 \mu \mathrm{l}$ of bacterial suspension, were placed in a methanol refrigeration bath at $-3.5^{\circ} \mathrm{C}$. After $5 \mathrm{~min}$, the test tubes were examined for ice formation. Strains were stored by lyophilization (8) in 1986, and by freezing suspensions mixed with glycerol in 1987.

When collections were completed for 1986, strains were stabbed into petri dishes containing autoclaved NGA amended with $16,32,45,64,90,128,181,256,362$, or $512 \mu \mathrm{l}$ of cupric hydroxide (Kocide 606) per liter of medium. Each strain was tested against each concentration of cupric hydroxide. Strains were randomized, and up to 24 were stabbed into the medium in each plate. The presence or absence of a halo of growth at each stab was recorded after 5 days' incubation at $22^{\circ} \mathrm{C}$. American Type Culture Collection isolates of $P$. syringae pv. syringae (type strain ATTC 19310) and $P$. syringae pv. phaseolicola (neopathotype strain, ATTC 19304) were also tested. Levels of copper resistance were compared using an analysis of variance.

Pathogenicity tests. Bacterial suspensions of $P$. syringae pv. phaseolicola strains were adjusted to $10^{9} \mathrm{CFU} / \mathrm{ml}$ in sterile phosphate buffer and used to soak a sterile gauze pad. A florist's frog was used to puncture half-expanded trifoliate leaves (supported by the saturated pad) of 4week-old cv. Olathe bean plants. Inoculated plants were placed in a mist chamber for $24 \mathrm{~h}$, then transferred to the greenhouse at $25 \pm 3^{\circ} \mathrm{C}$ and examined 10 days after inoculation for evidence of water-soaking around puncture wounds. Plants inoculated with sterile water showed no water-soaking. Isolations from plants exhibiting water-soaking showed that $P$. syringae pv. phaseolicola was present in tissue surrounding wounded areas. Strains identified as $P$. syringae pv. syringae were assayed for pathogenicity by D. E. Legard using a pod inoculation method at Cornell University (3).

\section{RESULTS AND DISCUSSION}

Bactericide efficacy and epiphytic populations. Copper-based bactericides had a variable effect on epiphytic bacterial populations recovered in these experiments, as they have in other studies $(4,18,24)$. Results at the Fort Collins research farm were not conclusive in 1987 (Table 1). The early presence of foliar bacterial disease symptoms prior to bactericide application precluded the sampling of symptomless leaflets, and made it possible only to sample flower populations. Halo blight symptoms were observed to spread through the field from a single plot designated for treatment with Tenn-Cop. The presence of disease symptoms and high epiphytic populations were both centered around this diseased plot, resulting in quite variable epiphytic levels across the field. Though the flower epiphytic population ranking of the different copper for-

Table 1. Epiphytic bacterial populations ( $\log _{10}$ CFU per 40 flowers; standard error in parentheses) recovered from pinto bean plants under different copper-based bactericide regimes at the research station in Fort Collins, Colorado, during 1987

\begin{tabular}{|c|c|c|c|c|}
\hline \multirow[b]{2}{*}{ Treatment } & \multicolumn{4}{|c|}{ Julian Day } \\
\hline & $182^{\mathrm{a}}$ & 189 & 201 & 220 \\
\hline \multicolumn{5}{|c|}{ Pseudomonas syringae population estimates } \\
\hline Control & $3.6(0.08)$ & $4.3(0.75)$ & $4.7(0.95)$ & $5.4(1.06)$ \\
\hline Copper Count $\mathrm{N}$ & $3.6(0.08)$ & $3.8(0.22)$ & $4.4(0.50)$ & $3.6(0.08)$ \\
\hline Tenn - Cop & $4.7(1.13)$ & $4.9(0.94)$ & $4.8(1.07)$ & $4.5(0.88)$ \\
\hline Champion & $3.6(0.08)$ & $4.3(0.76)$ & $4.3(0.63)$ & $4.1(0.52)$ \\
\hline Kocide & $3.6(0)$ & $3.6(0)$ & $4.0(0.39)$ & $3.9(0.32)$ \\
\hline \multicolumn{5}{|c|}{ Total bacterial population estimates } \\
\hline Control & $6.2(0.19)$ & $6.4(0.17)$ & $6.3(0.41)$ & $6.9(0.28)$ \\
\hline Copper Count $\mathrm{N}$ & $6.1(0.14)$ & $6.1(0.10)$ & $5.6(0.17)$ & $\underline{5.5}(0.16)^{b}$ \\
\hline Tenn - Cop & $6.8(0.42)$ & $6.6(0.34)$ & $6.4(0.56)$ & $6.1(0.40)$ \\
\hline Champion & $6.3(0.16)$ & $6.1(0.24)$ & $6.0(0.22)$ & $\mathbf{5 . 4}(0.11)^{\mathrm{c}}$ \\
\hline Kocide & $6.3(0.09)$ & $6.3(0.09)$ & $6.1(0.10)$ & $5.7(0.26)$ \\
\hline
\end{tabular}

${ }^{a}$ There were $0,1,2$, and 4 applications of bactericides made before plant samples were recovered on Julian Dates 182, 189, 201, and 220, respectively.

${ }^{\mathrm{b}}$ Underlined entries are significantly different from the control $(P<0.05)$.

${ }^{\mathrm{c}}$ Bold entry is significantly different from the control based on the Bonferroni-corrected criterion $(P<0.002)$. 
mulations was not consistent over years (data not presented for 1986 due to midseason hail damage), in both years the nontreated plots had the highest mean population at the end of the sampling period. High epiphytic levels were still present in the treated plots.

In 1986 at Holyoke, bactericides were effective in reducing leaflet and flower $P$. syringae-type populations at both fields, although populations on treated plots rose toward the end of the season (Table 2).
Flower populations increased from midseason in both non-treated and some treated plots. The total population of bacterial epiphytes, though reduced in treated plots, was still high. Control late into the season in field 2 was consistent with Menkissoglu and Lindow's (22) finding that free $\mathrm{Cu}^{2+}$ ions on cupric hydroxidetreated leaves increased for 10 to 20 days after application. A comparison of total bacterial epiphyte populations on pods was possible on the final sampling date at field
1. P. syringae-type bacterial populations from pods could not be determined successfully by plating on $\mathrm{KB}$ for most sites because of the great numbers of mucoid, rapidly growing, fluorescent bacteria which were also recovered from pods. Total population counts of bacteria from pods showed low variance, and cupric hydroxide significantly reduced total bacteria on pods (Table 2). Overall at both Holyoke sites in 1986, there was evidence of a reduction in both $P$. syringae-type popula-

Table 2. Epiphytic bacterial populations ( $\log _{10} \mathrm{CFU}$ per 40 leaflets, flowers, or pods; standard error in parentheses) recovered from pinto bean plants untreated or treated with cupric hydroxide in two commercial fields in eastern Colorado during 1986

\begin{tabular}{|c|c|c|c|c|c|c|}
\hline \multirow[b]{2}{*}{ Field / tissue } & \multirow[b]{2}{*}{ Treatment } & \multicolumn{5}{|c|}{ Julian Day } \\
\hline & & $198^{\mathrm{a}}$ & 205 & 212 & 219 & 233 \\
\hline \multicolumn{7}{|c|}{ Pseudomonas syringae population estimates } \\
\hline \multirow[t]{2}{*}{1 / leaflets } & Control & $4.1(0.50)$ & $4.3(0.51)$ & $4.8(0.55)$ & & \\
\hline & Treated & $3.8(0.08)$ & $3.6(0)$ & $3.6(0)$ & & \\
\hline \multirow[t]{2}{*}{1 / flowers } & Control & & $3.7(0.09)$ & $4.9(0.45)$ & $4.5(0.43)$ & \\
\hline & Treated & & $3.9(0.30)$ & $\underline{3.6}(0)^{\mathrm{b}}$ & $\underline{3.6}(0)$ & \\
\hline \multirow[t]{2}{*}{2 / leaflets } & Control & $5.6(0.33)$ & $6.7(0.13)$ & $\overline{7.4}(0.16)$ & & $7.2(0.26)$ \\
\hline & Treated & $5.0(0.43)$ & $\underline{4.3}(0.48)^{\mathrm{c}}$ & $\underline{\mathbf{3 . 9}}(0.21)$ & & $\underline{6.3}(0.33)$ \\
\hline \multirow[t]{2}{*}{2 / flowers } & Control & & $\overline{3.6}(0)$ & $\overline{4.7}(0.69)$ & $5.6(0.17)$ & \\
\hline & Treated & & $3.6(0)$ & $3.7(0.17)$ & $4.8(1.22)$ & \\
\hline \multicolumn{7}{|c|}{ Total bacterial population estimates } \\
\hline \multirow[t]{2}{*}{1 / leaflets } & Control & $6.8(0.09)$ & $6.6(0.05)$ & $6.9(0.03)$ & & \\
\hline & Treated & $6.3(0.11)$ & $\underline{\mathbf{5 . 8}}(0.12)$ & $5.9(0.48)$ & & \\
\hline \multirow[t]{2}{*}{1 / flowers } & Control & & $\overline{6.4}(0.24)$ & $\overline{6.8}(0.14)$ & $6.8(0.13)$ & \\
\hline & Treated & & $6.3(0.18)$ & $\underline{5.7}(0.22)$ & $6.1(0.20)$ & \\
\hline \multirow[t]{2}{*}{$1 /$ pods } & Control & & & & $8.1(0.05)$ & \\
\hline & Treated & & & & $\mathbf{7 . 8}(0.05)$ & \\
\hline \multirow[t]{2}{*}{2 / leaflets } & Control & $7.2(0.06)$ & $7.6(0.13)$ & $7.9(0.05)$ & & $8.4(0.17)$ \\
\hline & Treated & $7.1(0.21)$ & $\mathbf{6 . 5}(0.08)$ & $7.0(0.52)$ & & $7.7(0.22)$ \\
\hline \multirow[t]{2}{*}{2 / flowers } & Control & & $\overline{7.6}(0.06)$ & $7.5(0.22)$ & $7.5(0.01)$ & \\
\hline & Treated & & 6.9 (0.09) & $6.7(0.12)$ & $\underline{6.8}(0.02)$ & \\
\hline
\end{tabular}

${ }^{a}$ There were 1, 2, 3, and 4 applications of cupric hydroxide made before plant samples were recovered on Julian Dates 198, 205, 212, and 219, respectively.

${ }^{\mathrm{b}}$ Underlined entries are significantly different from the control $(P<0.05)$.

${ }^{c}$ Bold entries are significantly different from the control based on the Bonferroni-corrected criterion $(P<0.004)$.

Table 3. Epiphytic bacterial populations ( $\log _{10}$ CFU per 40 leaflets or flowers; standard error in parentheses) recovered from pinto bean plants untreated or treated with cupric hydroxide in two commercial fields in eastern Colorado during 1987

\begin{tabular}{|c|c|c|c|c|c|c|c|}
\hline \multirow[b]{2}{*}{ Field / tissue } & \multirow[b]{2}{*}{ Treatment } & \multicolumn{6}{|c|}{ Julian Day } \\
\hline & & $190^{\mathrm{a}}$ & 198 & 205 & 211 & 219 & 225 \\
\hline \multicolumn{8}{|c|}{ Pseudomonas syringae population estimates } \\
\hline \multirow{2}{*}{3 / leaflets } & Control & $8.2(0.11)$ & & & & & \\
\hline & Treated & $8.0(0.15)$ & & & & & \\
\hline \multirow[t]{2}{*}{3 / flowers } & Control & & $6.9(0.28)$ & & $4.1(0.35)$ & & \\
\hline & Treated & & $6.6(0.21)$ & & $3.6(0)$ & & \\
\hline \multirow[t]{2}{*}{4 / leaflets } & Control & & & $4.9(0.71)$ & $4.5(0.51)$ & & \\
\hline & Treated & & & $4.5(0.91)$ & $4.5(0.56)$ & & \\
\hline \multirow[t]{2}{*}{4 / flowers } & Control & & & $3.8(0.18)$ & $3.6(0)$ & $5.9(0.80)$ & $5.4(0.64)$ \\
\hline & Treated & & & $3.6(0)$ & $3.6(0)$ & $\underline{3.6}(0)^{\mathrm{b}}$ & $4.5(0.94)$ \\
\hline \multicolumn{8}{|c|}{ Total bacterial population estimates } \\
\hline \multirow[t]{2}{*}{3 / leaflets } & Control & $8.2(0.11)$ & & & & & \\
\hline & Treated & $8.0(0.15)$ & & & & & \\
\hline \multirow[t]{2}{*}{3 / flowers } & Control & & $7.4(0.10)$ & & $6.2(0.09)$ & & \\
\hline & Treated & & $7.2(0.07)$ & & $\underline{5.6}(0.26)$ & & \\
\hline \multirow[t]{2}{*}{4 / leaflets } & Control & & & $6.5(0.14)$ & $\overline{5.8}(0.32)$ & & \\
\hline & Treated & & & $6.2(0.34)$ & $5.4(0.25)$ & & \\
\hline \multirow[t]{2}{*}{4 / flowers } & Control & & & $5.8(0.22)$ & $6.2(0.02)$ & $7.4(0.20)$ & $6.7(0.14)$ \\
\hline & Treated & & & $5.6(0.10)$ & $6.7(0.22)$ & $6.6(0.37)$ & $6.2(0.53)$ \\
\hline
\end{tabular}

${ }^{a}$ At field 3, there were 0, 1, 2, 3, and 4 applications of cupric hydroxide made before plant samples were recovered on Julian Dates 190, 198, 205, 211, and 219, respectively. At field 4, there were $0,1,2$, and 3 applications before samples were recovered on Julian Dates 205, 211, 219, and 225, respectively.

${ }^{\mathrm{b}}$ Underlined entries are significantly different from the control $(P<0.05)$. No differences were significant based on the Bonferroni-corrected criteria $P=$ 0.008 (field 3) or $P=0.004$ (field 4). 
tions and total epiphytic bacterial populations, especially after several applications of bactericide.

An early outbreak of halo blight in the Holyoke area in 1987 made sampling symptomless leaflets difficult. There was no evidence of control by bactericide applications of either epiphytic $P$. syringaetype bacteria or total epiphytic bacteria from the small number of leaflet samples obtained (Table 3). There was some evidence of a reduction in epiphytic flower population counts, and populations in nontreated plots were almost always higher on average than in treated plots, but the magnitude of reduction of epiphytes was not great.

During both years at the Holyoke sites, copper-based bactericides were more effective at reducing total epiphytic bacterial counts than at reducing epiphytic $P$. syringae-type counts. This may have occurred because $P$. syringae-type bacteria were sheltered in microscopic lesions, or simply because other epiphytic bacteria were more sensitive to copper bactericides. Populations recovered by plating on $\mathrm{KB}$ tended to be either dominated by $P$. syringae-type bacteria or apparently free from them.

No $P$. syringae pv. syringae strains were recovered in 1987 . When $P$. syringae-type strains from either year were tested for carbon source utilization, a few strains did not exhibit the pattern of usage considered characteristic for $P$. syringae pv. syringae or $P$. syringae pv. phaseolicola. It seems likely that as $P$. syringae is studied more carefully, more of the intermediate forms such as these and the FD (pathogenic bacteria resembling $P$. syringae) described by Leben and Miller (17) will be identified.

Total bacterial counts generally showed less variation than counts of $P$. syringaetype bacteria. Perhaps this was because the great variety of morphological types observed acted as a buffer to keep population levels more constant in the face of macroclimatic and microclimatic changes. Samples would occasionally appear to be dominated by a particular type other than $P$. syringae. It is likely that a variety of complex interactions occur on the leaf surface; the fact that copper-based bactericides reduce total bacterial epiphyte population counts may or may not be useful in controlling halo blight and bacterial brown spot, since other epiphytes may compete with and/or inhibit $P$. syringae development on surfaces. Conversely, they may have synergistic reactions with $P$. syringae as does Achromobacter, a bacterium which may be present inside bean plants (21).

The great variability typically found in bacterial population counts (10) was a problem in relating flower and leaflet population counts to each other. Among the potential sources of variability are rain and overhead irrigation, which can remove bactericide residues and reduce efficiency or can help redistribute the pesticide, depending on moisture intensity and duration. Dew was often present in mornings at Holyoke sites and may also have contributed to the redistribution of bactericides on

The relationship between flower and leaflet populations was considered for the sampling dates when both organs could be collected: the second and third leaflet samples at fields 1 and 2 in 1986 (Table 2). There was a great deal of variability between individual plots, and many plots with a high leaflet population count had no detectable flower populations. The means for total bacterial epiphyte populations were near a one-to-one relationtions showed a tendency toward higher the cases in which leaflet populations were much higher than flower populations, there were microscopic lesions or other favorable foliar niches supporting the larger leaflet populations.

While a single leaflet (or flower or pod) is one intuitive standard unit of plant material for sampling, we collected 40 leaflets in a bulked sample in an effort to represent the population in an experimental plot. Bacterial counts per leaflet have been observed to be lognormally distributed (11). Just as a single leaflet sample may give an overestimate for the mean number of bacteria per $g$ plant material, a bulk sample of plant surfaces. ship. Means for $P$. syringae-type populaleaflet populations. It is possible that for

40 leaflets may overestimate the mean number of bacteria per leaflet (16). Because we do not have representative data for the distribution of single-leaflet bacterial counts, we lack information to construct a bias-corrected estimate of mean count per single leaflet. For this reason, our results are presented in terms of CFU/40 leaflets. What standard unit of plant material might be most useful for predicting disease incidence from epiphytic counts is an open question.

Copper resistance. Analysis of copper resistance was based on 204 P. syringae pv. syringae strains (mean highest survival concentration $[\mathrm{MHSC}]=306 \mu \mathrm{l} /$ liter medium, SD $=65)$ and $166 P$. syringae $\mathrm{pv}$. phaseolicola strains $(\mathrm{MHSC}=107, \mathrm{SD}=$ 32) recovered during 1986 . Of the $P$. syringae pv. syringae strains, $9 \%$ were from the Fort Collins site (MHSC $=303, \mathrm{SD}=86$ ) and the others were from Holyoke sites (MHSC $=307, \mathrm{SD}=62$ ); of the $P$. syringae pv. phaseolicola strains, $96 \%$ were from the Fort Collins site (MHSC $=105$, $\mathrm{SD}=29$ ) and the others were from Holyoke sites $(\mathrm{MHSC}=142, \mathrm{SD}=64)$. Among the experimental factors examined in 1986, only the difference between pathovars had a significant effect $(P<$ 0.0001 ; Fig. 1) on copper resistance of recovered strains as measured in vitro. The differences between ATCC strains were similar to the differences observed in Colorado strains. $P$. syringae pv. syringae

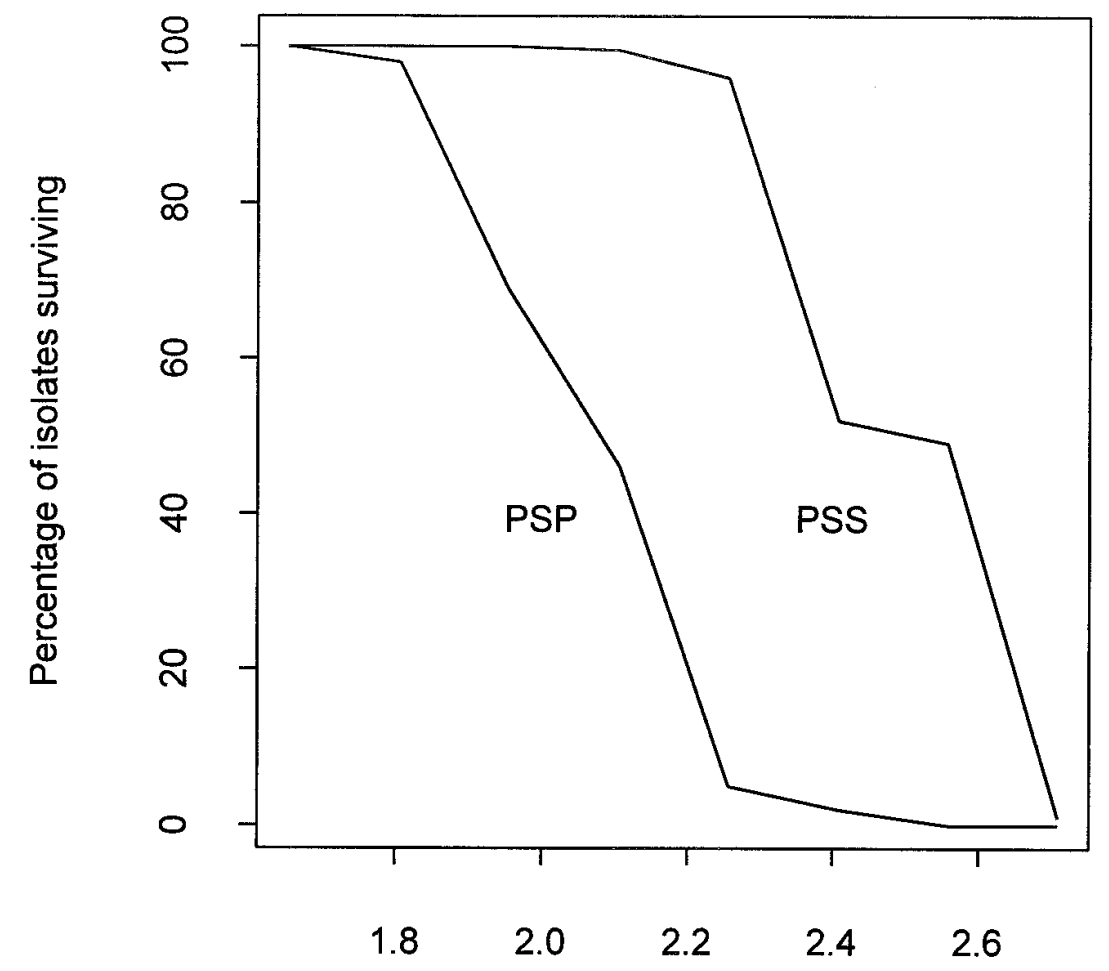

\section{Log microliters cupric hydroxide per liter medium}

Fig. 1. Levels of cupric hydroxide resistance in epiphytic strains of Pseudomonas syringae pv. syringae and $P$. syringae pv. phaseolicola recovered from pinto dry beans during 1986. 
(ATCC 19310) grew up to the level of 256 $\mu \mathrm{l}$, and P. syringae pv. phaseolicola (ATCC 19304) grew only up to the level of $128 \mu \mathrm{l}$ Kocide 606/liter NGA. The colony morphology of the two pathovars also differed as their growth was suppressed at higher copper levels in vitro. As the copper concentration increased, $P$. syringae pv. phaseolicola colonies became thinner and maintained their diameter, while colonies of $P$. syringae pv. syringae maintained their thickness and were reduced in diameter. There was no consistent trend in level of resistance over time at the sites or in bactericide-treated plots compared to non-treated plots. Garrett (7) gives more detailed results of copper resistance analyses.

If selection for resistant populations occurred in the presence of a copper-based bactericide, it would be important to determine whether there is significant selection against copper resistant strains in the absence of copper-based bactericides. For example, copper resistance was associated with avirulence in Xanthomonas campestris pv. vesicatoria (27). But Sundin and Bender (28) have demonstrated that $P$. syringae pv. syringae strains with plasmids encoding copper resistance may have approximately the same performance as plasmid-free strains growing as epiphytes on bean leaves. Work by Bender and Cooksey $(1,2)$ demonstrated that plasmids conferring increased copper resistance may be transferred from one $P$. syringae pathovar to another. If the greater copper resistance found in $P$. syringae pv. syringae isolates was determined by a plasmid, it might be transferred to $P$. syringae pv. phaseolicola. As of 1997, we are not aware of evidence that copper-based bactericides have become less effective for controlling halo blight and bacterial brown spot. Typically, only 2 to 4 applications are used on beans, while tomato or pepper may receive 6 to 20 applications, and the selection pressure on beans may be relatively low. Models of the development of bactericide resistance suggest that it may take several years before resistant populations can reach a detectable level (13). If resistant strains came to dominate $P$. syringae populations, and if they were as fit as the wild genotypes in Colorado, they could be maintained from year to year in infected seed that germinates to produce volunteer beans (18).

Pathogenicity tests for $P$. syringae pv. phaseolicola gave positive results for $93 \%$ of the strains tested, while only $5 \%$ of the $P$. syringae pv. syringae strains gave positive results. The pathogenicity test used for $P$. syringae pv. syringae was developed using strains from the eastern United States (3), and regional differences might contribute to the low percentage of pathogenicity detected in the strains from the western United States; or, these strains may be intermediate forms, which are non- pathogenic or express pathogenicity differently. The five pathogenic strains were all from field 2 in Holyoke and had typical levels of copper resistance in our in vitro tests.

In 1987, when the growing season began with cool, wet weather, pathovar phaseolicola dominated the epiphytic $P$. syringaetype population throughout the season. Earlier work in Colorado revealed a trend toward an increased percentage of epiphytic $P$. syringae pv. phaseolicola over the course of the season (18). This may have been caused by the typically cooler and wetter environmental conditions which favor $P$. syringae pv. phaseolicola development near the end of the season. When field data were examined to determine if there was a difference between the two pathovars in susceptibility to copper-based bactericide application, the small number of strains collected from treated samples precluded statistical analysis. Only field 2 in 1986 had significant populations of both pathovars. At this site, $P$. syringae pv. phaseolicola comprised a lower percentage of $P$. syringae strains recovered from bactericide-treated plants than in samples from non-treated plants throughout the sampling period. Currently, bacterial brown spot is a greater problem than halo blight in eastern Colorado, western Kansas, and western Nebraska (H. F. Schwartz, unpublished data). If the difference in in vitro copper resistance between the cultivars found in the $1980 \mathrm{~s}$ persists in current bacterial populations, copper-based bactericides may be more effective for controlling halo blight than for controlling bacterial brown spot.

\section{ACKNOWLEDGMENTS}

We thank M. McMillan, P. Stutheit, J. Taggert, and L. Wierdsma for technical assistance; M. Brick, P. Chapman, G. Franc, M. Harrison, J. Hill, D. Hopkins, D. Legard, H. Scheck, and two anonymous reviewers for their comments on earlier versions of this work; and the cooperators with Jack's Bean Company in Holyoke, Colorado, for making that portion of our research possible.

\section{LITERATURE CITED}

1. Bender, C. L., and Cooksey, D. A. 1986. Indigenous plasmids in Pseudomonas syringae pv. tomato: conjugative transfer and role in copper resistance. J. Bacteriol. 165:534541.

2. Bender, C. L., and Cooksey, D. A. 1987. Molecular cloning of copper resistance genes from Pseudomonas syringae pv. tomato. J. Bacteriol. 169:470-474.

3. Cheng, G. Y., Legard, D. E., Hunter, J. E., and Burr, T. J. 1989. Modified bean pod assay to detect strains of Pseudomonas syringae pv. syringae that cause bacterial brown spot of snap bean. Plant Dis. 73:419-423.

4. Conlin, K. C., and McCarter, S. M. 1983. Effectiveness of selected chemicals in inhibiting Pseudomonas syringae pv. tomato in vitro and in controlling bacterial speck. Plant Dis. 67:639-644.

5. Cooksey, D. A. 1990. Genetics of bactericide resistance in plant pathogenic bacteria. Annu. Rev. Phytopathol. 28:201-219.
6. Dunnett, C. W. 1955. A multiple comparisons procedure for comparing several treatments with a control. J. Am. Stat. Assoc. 50:10961121.

7. Garrett, K. A. 1991. Dynamics of Epiphytic Pseudomonas syringae Populations on Dry Beans Treated with Copper-Based Pesticides. Master's Thesis, Colorado State Univ., Fort Collins, Colorado.

8. Gitaitis, R. D. 1987. Refinement of lyophilization methodology for storage of large numbers of bacterial strains. Plant Dis. 71:615616.

9. Harris, R. F., and Sommers, L. E. 1968. Platedilution frequency technique for assay of microbial ecology. Appl. Microbiol. 16:330-334

10. Hirano, S. S., Clayton, M. K., and Upper, C D. 1994. Estimation of and temporal changes in means and variances of populations of Pseudomonas syringae on snap bean leaflets. Phytopathology 84:934-940.

11. Hirano, S. S., Nordheim, E. V., Arny, D. C., and Upper, C. D. 1982. Lognormal distribution of epiphytic bacterial populations on leaf surfaces. Appl. Environ. Microbiol. 44:695700 .

12. Hirano, S. S., and Upper, C. D. 1990. Population biology and epidemiology of Pseudomonas syringae. Annu. Rev. Phytopathol. 28:155-177.

13. Kable, P. F., and Jeffery, H. 1980. Selection for tolerance in organisms exposed to sprays of biocide mixtures: a theoretical model. Phytopathology 70:8-12.

14. Kennedy, B. W., and Alcorn, S. M. 1980 Estimates of U. S. crop losses to prokaryote plant pathogens. Plant Dis. 64:674-676.

15. King, E. O., Ward, M. K., and Raney, D. E. 1954. Two simple media for the demonstration of pyocyanin and fluorescin. J. Lab. Clin. Med. 44:301-307.

16. Kinkel, L. L., Wilson, M., and Lindow, S. E. 1995. Effect of sampling scale on the assessment of epiphytic bacterial populations. Microb. Ecol. 29:283-297.

17. Leben, C., and Miller, T. D. 1973. A pathogenic pseudomonad from healthy field-grown soybean plants. Phytopathology 63:14641467.

18. Legard, D. E., and Schwartz, H. F. 1987. Sources and management of Pseudomonas syringae pv. phaseolicola and Pseudomonas syringae pv. syringae epiphytes on dry beans in Colorado. Phytopathology 77:1503-1509.

19. Lindemann, J., Arny, D. C., and Upper, C. D. 1984. Epiphytic populations of Pseudomonas syringae pv. syringae on snap bean and nonhost plants and the incidence of bacterial brown spot disease in relation to croppng patterns. Phytopathology 74:13291333.

20. Lindemann, J., Arny, D. C., and Upper, C. D. 1984. Use of an apparent infection threshold population of Pseudomonas syringae to predict incidence and severity of brown spot of bean. Phytopathology 74:1334-1339.

21. Maino, A. L., Schroth, M. N., and Vitanza, V. B. 1974. Synergy between Achromobacter sp. and Pseudomonas phaseolicola resulting in increased disease. Phytopathology 64:277283.

22. Menkissoglu, O., and Lindow, S. E. 1991. Chemical forms of copper on leaves in relation to the bactericidal activity of cupric hydroxide deposits on plants. Phytopathology 81:1263-1270.

23. Milliken, G. A., and Johnson, D. E. 1984. Analysis of Messy Data. Vol. 1: Designed Experiments. Van Nostrand Reinhold, New York.

24. Olson, B. D., and Jones, A. L. 1983. Reduction of Pseudomonas syringae pv. morsprunorum on Montmorency sour cherry with cop- 
per and dynamics of the copper residues. Phytopathology 73:1520-1525.

25. Schaad, N. W., editor. 1988. Laboratory Guide for Identification of Plant Pathogenic Bacteria, 2nd Edition. APS Press, St. Paul, $\mathrm{MN}$.

26. Scheck, H. J., Pscheidt, J. W., and Moore, L. W. 1996. Copper and streptomycin resistance in strains of Pseudomonas syringae from $\mathrm{Pa}-$ cific Northwest nurseries. Plant Dis. 80:10341039.

27. Stall, R. E., Loschke, D. C., and Jones, J. B. 1986. Linkage of copper resistance and avirulence loci on a self-transmissible plasmid in Xanthomonas campestris pv. vesicatoria. Phytopathology 76:240-243.

28. Sundin, G. W., and Bender, C. L. 1994. Relative fitness in vitro and in planta of Pseudo- monas syringae strains containing copper and streptomycin resistance plasmids. Can. J. Microbiol. 40:279-285.

29. Sundin, G. W., Jones, A. L., and Fulbright, D. W. 1989. Copper resistance in Pseudomonas syringae pv. syringae from cherry orchards and its associated transfer in vitro and in planta with a plasmid. Phytopathology 79:861-865. 